\title{
MDR1-Pgp 170 expression in human bronchus
}

\author{
E. Lechapt-Zalcman*, I. Hurbain*, R. Lacave*, F. Commo**, T. Urban*, M. Antoine**, \\ B. Milleron+, J.F. Bernaudin*
}

MDRI-Pgp 170 expression in human bronchus. E. Lechapt-Zalcman, I. Hurbain, R. Lacave, F. Commo, T. Urban, M. Antoine, B. Milleron, J.F. Bernaudin. (CERS Journals Ltd 1997.

ABSTRACT: MDR1 P-glycoprotein (Pgp 170), a member of the adenosine triphosphate (ATP) binding cassette transporters, acts as an efflux pump for various hydrophobic agents, particularly for xenobiotics such as benzo(a)pyrene. It has also been shown to regulate cell-volume activated chloride channels. Pgp 170 could, therefore, be of particular importance in cellular mechanisms of defence in the airways and in the control of mucus layer composition. For these reasons, we evaluated the precise localization of Pgp 170 in human adult airways.

Fresh non-neoplastic bronchial specimens were collected from 33 patients (26 smokers, four exsmokers and three nonsmokers) who underwent surgery for lung carcinoma. The presence of MDR1 messenger ribonucleic acid (mRNA) was demonstrated by reverse transcriptase chain reaction (RT-PCR) in bronchial epithelial cells collected by gentle scraping from either smokers, exsmokers or nonsmokers. Immunodetection of Pgp 170 using a panel of monoclonal antibodies (MRK16, JSB1, C219, C494) was performed either on cryostat or paraffin-embedded sections of histologically normal bronchial tissue.

Pgp 170 was constantly detected with intense labelling at the apical surface of ciliated epithelial cells from the surface epithelium or ciliated collecting ducts, and on apical and lateral surfaces of serous cells from bronchial glands. No staining of mucus-secreting cells was observed. Pgp 170 was also demonstrated at the luminal surface of endothelial cells of bronchial capillaries.

In conclusion, the expression of MDR1 P-glycoprotein in bronchial structures, particularly at the epithelial apical surface, suggests important roles for this transmembrane protein in human airways.

Eur Respir J 1997; 10: 1837-1843.
*Histology and Tumour-Biology Laboratory, **Pathology Laboratory and +Dept of Chest Medicine, Hôpital Tenon, Paris, France.

Correspondence: J.F. Bernaudin Hôpital Tenon

Laboratoire d'Histologie-Biologie Tumorale 4 , rue de la Chine

75020 Paris

France

Keywords: Human bronchus MDR1

P-glycoprotein

xenobiotics

Received: January 311996

Accepted after revision May 101997

This work was supported by a grant from the Association Française de Lutte contre la Mucoviscidose, 1994, France. EL-Z received a grant from the Fondation pour la Recherche Médicale.
Transmembrane transporters, related to specific membrane-associated proteins, serve a wide variety of cellular roles, particularly concerning the interaction between organisms and their environment. One of the families of transmembrane transporters is characterized by a highly conserved adenosine triphosphate (ATP) binding cassette $(A B C)$ and members of this family are, therefore, referred to as $\mathrm{ABC}$ transporters [1-3]. The ABC transmembrane transporters are responsible for functions as varied as chloride channel, xenobiotics and multidrug cellular export, and glutathione S conjugate transport, mainly via CFTR, MDR and MRP proteins respectively [1-9].

MDR1 P-glycoprotein (Pgp 170) was identified after comparison of hydrophobic drug-sensitive and drug-resistant cell lines characterizing the multidrug-resistance (MDR) phenotype. The genes coding for this protein have therefore been identified as $M D R$ genes [10-14]. Two isoforms of the P-glycoprotein were subsequently identified, coded in humans by the MDR1 and MDR2/MDR3 genes $[3,15]$. The MDR3 P-glycoprotein has been recently shown to be involved in phospholipid transport [16] and is expressed in human liver, but not in human lung [17].
MDR1 Pgp 170 is a cell-membrane ATP-dependent efflux pump with diverse substrate specificities, particularly for hydrophobic chemotherapeutic agents [2, $3,10,12]$. It has also been shown that MDR1 Pgp 170 has a role in the regulation of cell volume activated chloride channels [4]. MDR1 Pgp 170, expressed in normal tissues, has also recently been shown to actively transport benzo(a)pyrene not only in MCF 7 breast cancer cell line in vitro, but also in apical membrane vesicles obtained from normal human intestinal epithelium $[6,7]$.

MDR1 Pgp 170 appears to be a membrane-associated protein with a wide range of physiological roles, particularly in cell defence mechanisms against environmental attacks such as those generated by xenobiotics. MDR1 Pgp 170 could therefore be of particular physiological importance in cellular mechanisms of defence in airways and in the control of mucus layer composition. Previous succinct reports have indicated the presence of MDR1 Pgp 170 in normal human airways as well as in many other normal tissues. However, the precise localization of expressing cells has not yet been described [18-21]. 
The present study, using both immunohistochemistry detection of MDR1 Pgp 170 and reverse transcriptase polymerase chain reaction (RT-PCR) to detect MDR1 messenger ribonucleic acid (mRNA), was conducted to precisely localize and evaluate $M D R l$ gene expression in human adult bronchus from smokers, exsmokers and nonsmokers.

\section{Materials and methods}

\section{Patients}

Specimens from 33 patients from the Department of Chest Medicine of Hôpital Tenon who underwent surgery, i.e. pneumonectomy or lobectomy for a primary nonsmall cell pulmonary carcinoma $(n=31)$ or pulmonary metastasis $(n=2)$, between September 1993 and August 1996 were included in the present study. The age of the patients ranged 35-82 yrs (median 64 yrs). Twenty nine patients were men and four were women. Twenty six patients were heavy current smokers (i.e. more than 20 pack-years), four were exsmokers and three were nonsmokers. The four exsmokers had quit smoking 2-32 yrs before surgery $(2,7,10$ and 32 yrs); therefore, it was decided to combine exsmokers and nonsmokers in the same group. Eleven patients were randomly selected for immunohistochemical detection of MDR1 Pgp 170, and 22 for RT-PCR detection of MDR1 mRNA. The patients had not received any chemotherapy regimen or long-term treatment with drugs such as colchicine or antibiotics before surgery.

\section{Preparation of bronchial samples}

Fresh bronchial samples were prepared within $1 \mathrm{~h}$ of resection. Tumour and non-tumour samples were used for routine pathological diagnosis. Histologically normal bronchial tissue specimens were either immediately mounted in water soluble embedding medium for frozen tissue specimens (OCT; Ames Division, Miles, Elkhart, IN, USA), frozen in liquid nitrogen and stored at $-70^{\circ} \mathrm{C}$ until used, or fixed in phosphate buffered saline (PBS) ( $\mathrm{pH} 7.4)$ containing 4\% paraformaldehyde (PFA) for 3-4 h, followed by washing in 15\% sucrosePBS and snap-freezing. Additional samples were fixed for $6 \mathrm{~h}$ in cold $80 \%$ ethanol and paraffin-embedded.

\section{Isolation of bronchial respiratory epithelial cells}

Bronchial epithelial cells were collected by gentle scraping of the lumen of normal lobar or segmental bronchi collected at thoracotomy in seven patients. The quality of the samples was controlled by phase-contrast microscopy and May Grünwald Giemsa (MGG) staining of a cytocentrifuge preparation of the cells collected.

\section{Immunohistochemistry detection of MDRI P-glycoprotein}

Antibodies. Four anti-P-glycoprotein monoclonal antibodies (MoAbs) were used for immunostaining: MRK16, JSB1, C219 and C494. Three of these MoAbs have been shown not to be exclusively specific for MDR1 Pgp 170 , and it has been recommended that studies employ- ing immunohistochemical techniques should use a panel of antibodies that recognize at least two different epitopes of Pgp 170 to minimize false-positive results [22]. MRK16 (Valbiotech, Paris, France), an immunoglobulin (Ig)G2a antibody, is specific for the class I isoform (MDR1) of human P-glycoproteins. Its epitope is discontinuous and encompasses at least two (first and fourth) of the six predicted extracellular peptide loops [23, 24]. Negative reactivity with MRK16 must be interpreted cautiously, because the detection of its external epitope requires non-paraffin-embedded frozen tissues [23, 24]. C219 (CIS Bio International, Gifsur-Yvette, France), an $\mathrm{IgG} 2 \mathrm{a}$ antibody, recognizes an intracytoplasmic epitope found in all human P-glycoprotein isoforms [22, 25]. C494 (Signet Laboratories, Dedharn, MA, USA), an IgG2a antibody, is directed against an internal epitope different from $\mathrm{C} 219$, present in the human and hamster class I isoform [26]. JSB1 (Tebu, Le Perray en Yvelines, France) is an IgG1 antibody,

Immunohistochemistry procedure. Cryostat-cut tissue sections ( $4 \mu \mathrm{m}$ thick) were used, placed on slides coated with 3-aminopropyltriethoxysilane (Sigma, St. Louis, USA), air dried for $2 \mathrm{~h}$, and unfixed or fixed for $10 \mathrm{~min}$ with cold acetone. The sections were subsequently rinsed in PBS, incubated with blocking serum ( $10 \%$ normal goat serum in PBS containing 3\% bovine serum albumin) for $20 \mathrm{~min}$ at $20^{\circ} \mathrm{C}$, followed by incubation overnight at $4^{\circ} \mathrm{C}$ with MRK16 $\left(20 \mu \mathrm{g} \cdot \mathrm{mL}^{-1}\right), \mathrm{C} 219(10$ $\left.\mu \mathrm{g} \cdot \mathrm{mL}^{-1}\right), \mathrm{C} 494\left(10 \mu \mathrm{g} \cdot \mathrm{mL}^{-1}\right)$ or JSB1 $(1: 10)$ diluted in blocking serum. Biotinylated secondary antibody (Dako, Glostrup, Denmark) was applied for $30 \mathrm{~min}$, followed by a streptavidin-biotin-conjugated alkaline phosphatase complex reagent (Dako) for $30 \mathrm{~min}$ at $20^{\circ} \mathrm{C}$. After each step, the sections were washed repeatedly with PBS. Fast Red was used as chromogen. The sections were then exposed to a substrate solution containing naphthol AS-MX phosphate, Fast Red TR and levamisole (Dako) for $20 \mathrm{~min}$.

Sections ( $4 \mu \mathrm{m}$ thick) of paraffin-embedded bronchial tissue were cut, placed on coated slides and incubated overnight at $37^{\circ} \mathrm{C}$. The sections were dewaxed with xylene, and hydrated to water through a series of alcohol solutions. The streptavidin-biotin complex method, used for frozen samples, was applied with the following modifications: horseradish peroxidase-conjugated steptavidin (Dako) was used instead of alkaline phosphatase-conjugated steptavidin; endogenous peroxidase activity was blocked in $0.3 \%(\mathrm{v} / \mathrm{v})$ hydrogen peroxide in absolute methanol for $20 \mathrm{~min}$; and sections were exposed to a solution containing the diaminobenzidine chromogen for $10 \mathrm{~min}$.

Various negative controls were performed: substitution of the primary antibody by a murine antibody of the same subtype, at the same protein concentration; omitting either the primary antibody or the secondary antibody. Samples of normal human colonic mucosa were used as positive controls [27].

\section{Detection of MDR1 mRNA by RT-PCR}

Bronchial epithelial cells collected by scraping were pelleted by centrifugation $(1,200 \mathrm{rpm}$ for $20 \mathrm{~min}$ at, $+4^{\circ} \mathrm{C}$ ). The cells were disrupted using RNAzol ${ }^{\mathrm{TM}}$ (Bioprobes Systems, Montreuil sous Bois, France), and the 
total ribonucleic acid (RNA) was then extracted by adding chloroform to the homogenate and precipitated by isopropanol precipitation at $-20^{\circ} \mathrm{C}$. This method is derived from that previously described by CHOMSZYNSKI and SACCHI [28]. The total RNA was electrophoresed in 2\% agarose and the samples were checked to contain intact $28 \mathrm{~S}$ and $18 \mathrm{~S}$ ribosomal RNA. Total RNA was stored at $-80^{\circ} \mathrm{C}$ for up to 1 month.

The RT-PCR was performed with reverse transcriptase from superscript II (Gibco-BRL, Les Ulis, France). For reverse transcription, $2 \mu \mathrm{g}$ of RNA was added to $10 \mu \mathrm{L} 5 \times$ reverse transcriptase (RT) buffer (GibcoBRL), $5 \mu \mathrm{L}$ of $5 \mathrm{mM}$ deoxyribonucleoside triphosphates (dNTPs) deoxyadenosine triphosphate (dATP), deoxycytosine triphosphate (dCTP), deoxyguanosine triphosphate (dGTP), deoxythymidine triphosphate (dTTP)) (Boehringer Mannheim, France SA, Meylan, France), $0.5 \mu \mathrm{L} \mathrm{0.1} \mathrm{M} \mathrm{dithiothreitol} \mathrm{(DTT)} \mathrm{(Gibco-BRL),} 2.5 \mu \mathrm{L}$ random hexamer primers (Pharmacia, Biotech SA, Saint Quentin en Yvelines, France) and $1 \mu \mathrm{L}$ reverse transcriptase $200 \mathrm{U}$.

Sterile water was added to a final volume of $50 \mu \mathrm{L}$ and reverse transcription was immediately started at $37^{\circ} \mathrm{C}$ for $15 \mathrm{~min}$.

For polymerase chain reaction (PCR), $5 \mu \mathrm{L}$ aliquots of resulting complementary deoxyribonucleic acid (cDNA) were amplified in a $25 \mu \mathrm{L}$ reaction volume containing $2.5 \mu \mathrm{L}$ of $5 \mathrm{mM}$ dNTPs (dATP, dCTP, dGTP, dTTP), $2.5 \mu \mathrm{L} 10 \times$ PCR buffer, $2.5 \mathrm{mM} \mathrm{MgCl}{ }_{2}, 0.1 \mathrm{U}$ Taq deoxyribonucleic acid (DNA) polymerase (ATGC; Noisy le Grand, France) and $37.5 \mathrm{pM}$ of both primers.

After denaturation at $95^{\circ} \mathrm{C}$ for $10 \mathrm{~min}, 35$ cycles of $95^{\circ} \mathrm{C}$ for $60 \mathrm{~s}, 55^{\circ} \mathrm{C}$ for $60 \mathrm{~s}$, and $72^{\circ} \mathrm{C}$ for $120 \mathrm{~s}$ were performed in a thermal cycler (Thermoblock; Biometratrio, Kontron, Saint Quentin en Yvelines, France). Final extension lasted $7 \mathrm{~min}$.

PCR products were electrophoresed on a $2 \%$ agarose gel. Two pairs of PCR primers were used according to NOONAN et al. [29]: one pair hybridized to the MDR1 cDNA (MDR1, sense primer: 5' CCC ATC ATT GCA ATA GCA GG, residues 2596-2615; antisense primer: 3' GTT CAA ACT TCT GCT CCT GA, residues 2733-2752) and the other to the human $\beta_{2}$ microglobulin cDNA as an endogenous control (sense primer: 5' ACC CCC ACT GAA AAA GAT GA 3'; antisense primer: 5' ATC TTC AAA CCT CCA TGA TG 3'). The size of the amplified fragments was $167 \mathrm{bp}$ for MDR1 and $114 \mathrm{bp}$ for $\beta_{2}$ microglobulin.

The primer branching sites of each primer pair were selected on two different exons separated by one intron. PCR products from DNA and RNA could therefore be distinguished by size after gel electrophoresis. cDNA from KB 3.1 and 8.5 cell lines were used as negative and positive controls, respectively, for the detection of MDR1 mRNA, [29]. Negative control reactions were also performed by omitting RNA or cDNA template.

Quantitative RT-PCR analysis was performed on photographs from ethidium bromide stained agarose gels, scanned and analyzed with a computerized image analysis system (Imaging Densitometer GS 670; Biorad, Ivry sur Seine, France) [29]. For each of the 22 samples tested, the MDR1 mRNA content of bronchial epithelial cells was expressed as the ratio of MDR1 to $\beta_{2}$ microglobulin amplified products.

\section{Statistical analysis}

Quantitive RT-PCR analysis results from the 22 samples collected from smokers and non- and exsmokers were compared using the nonparametric Mann-Whitney U-test; a p-value of less than 0.05 was considered statistically significant.

\section{Results}

\section{Immunolocalization of MDR1 Pgp 170}

The distribution of MDR1 in the bronchus was similar in all individuals studied. Immunostaining on frozen sections was reproducible and reliable with the four MoAbs. No complementary immunoreactivity was detected with $\mathrm{C} 219$, which recognizes MDR1 as well as MDR2/MDR3 human P glycoproteins. The intensity of immunoreactivity for each antibody varied according to the fixation performed, or not performed, before freezing the tissues. After incubation with JSB1, C219 and C494, a strong staining was observed when samples were primarily snap-frozen without prior fixation. In contrast, the MRK16-reactive determinant was more clearly detected in tissues primarily fixed with $4 \%$ PFA before snap-freezing (figs. 1 and 2).

Specific immunoreactivity was lost after routine tissue fixation and paraffin embedding, as already reported [15]. Therefore, Pgp 170 detection was performed on paraffin-embedded tissue sections after ethanol fixation. Demonstrative results were obtained only with C494 antibody, and the immunohistochemical signal correlated with that obtained on frozen sections (figs. 1,2). In contrast, no staining was seen after incubation with MRK16 and a diffuse staining with JSB1 and C219.

After incubation of cryostat sections secondarily acetone-fixed with JSB1 and C219 antibodies, a marked labelling was observed on the apical membrane of ciliated cells in 11 and 10 out of 11 samples, respectively. Similar results were obtained on the sections of four of these samples incubated with the C494 antibody. Unfortunately, glands and capillaries were badly preserved by this processing and no clear observations were possible. After immunodetection of MDR1 Pgp 170 using the C494 MoAb on tissue sections after paraffin embedding, similar results were observed in the five samples tested. Staining was observed at the apical part of ciliated epithelial cells either on the surface epithelium or ciliated collecting ducts [30] (fig. 1).

Dense apico-lateral staining was observed in the acini of serous glands (fig. 2). No staining was observed on mucous cells from either the surface epithelium or glands. The endothelial surface of the capillaries of the lamina propria was heavily stained (fig. 2).

Similar results were obtained when using the MRK16 monoclonal antibody on bronchial cryostat sections from the samples PFA-fixed before deep freezing. As shown on figures 1 and 2 , intense labelling was observed on the apical surface of all the ciliated cells of the surface epithelium or ciliated ducts.

Staining was observed on the apical surface of serous glands, but not on the mucous parts (fig. 2). 

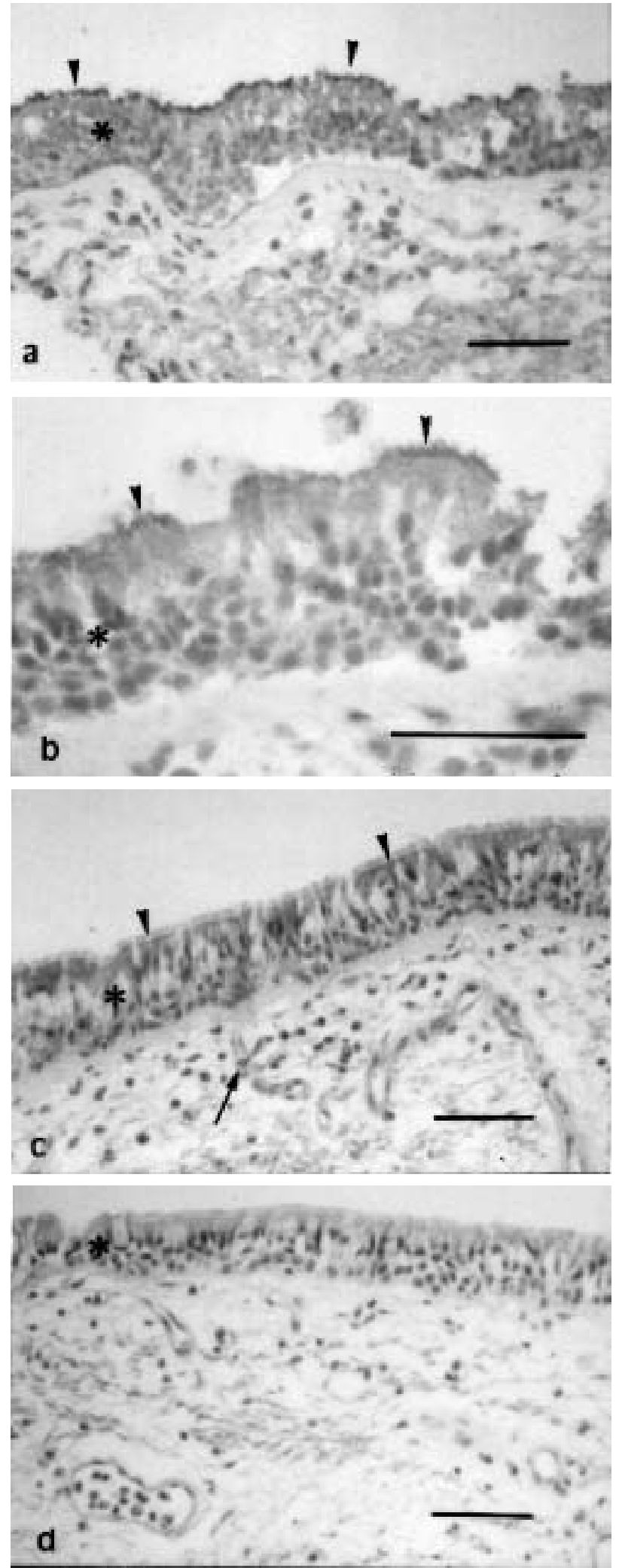

Fig. 1. - Bronchial mucosa covered by a well-preserved ciliated bronchial epithelium. Immunodetection of MDR1 P-glycoprotein (Pgp 170) on: a, b) cryostat sections using MRK16 monoclonal antibodies (MoAbs); c) paraffin-embedded section using C494 MoAb. Intense labelling of the apical surface of ciliated cells was observed $(\rightarrow)$ with both antibodies $(\mathrm{a}-\mathrm{c})$. Bronchial capillaries were also labelled with C494 (c). No staining was observed after incubation with nonimmune murine immunoglobulin G2a (d). Internal scale bars $=20 \mu \mathrm{m}$.
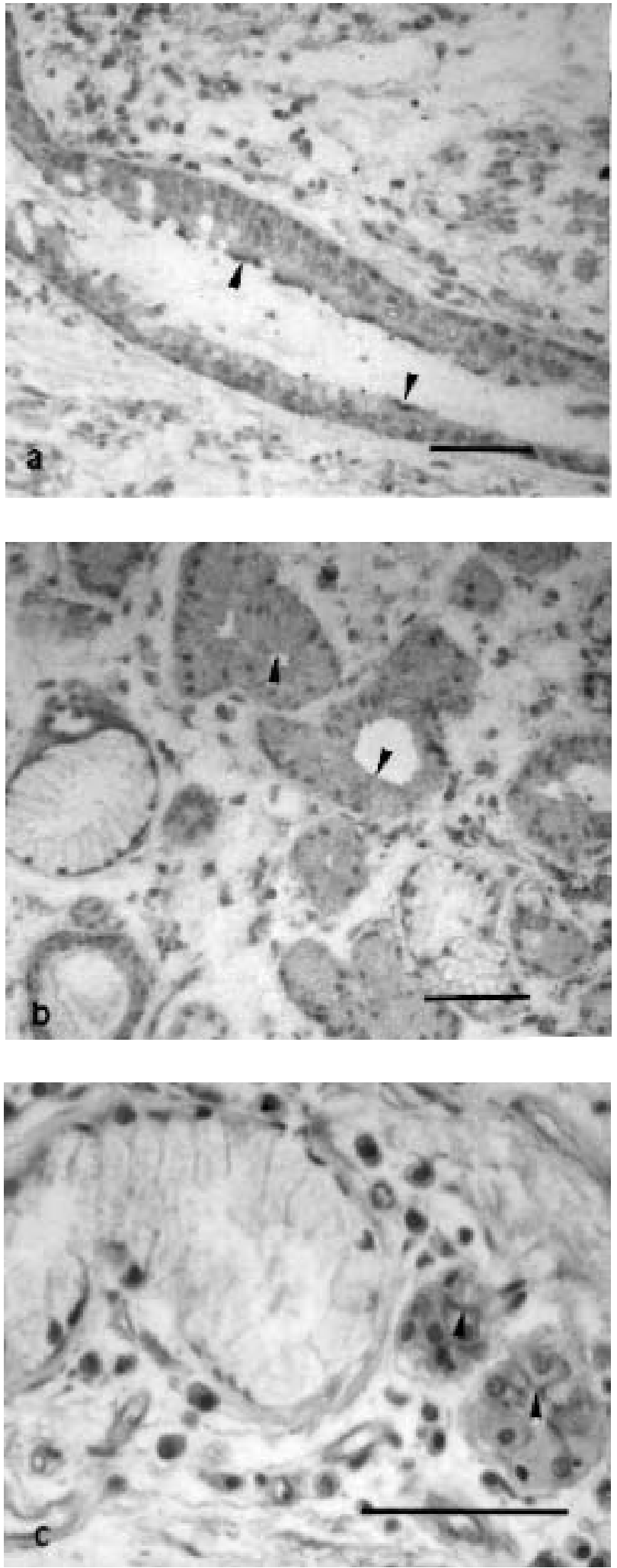

Fig. 2. - Bronchial glands: a, b) immunodetection of MDR1 P-glycoprotein (Pgp 170) on cryostat using MRK16 monoclonal antibodies (MoAb); or c) paraffin-embedded sections using C494 MoAb. Intense labelling was observed at the luminal surface of ciliated cells from collecting ducts (a), and on the apical and lateral faces of serous cells $(\rightarrow) ; b, c)$ No staining was observed on mucus-secreting cells. Bronchial capillaries were also intensely labelled (c). Internal scale bars $=20 \mu \mathrm{m}$. 
Intense labelling was observed in all bronchial capillary endothelial cells of the lamina propria, regardless of the antibody used. This labelling was observed at the luminal surface of the endothelium (fig. 2).

Negative results were obtained when using non-immune murine $\operatorname{IgG}$ instead of monoclonal antibody (fig. 1).

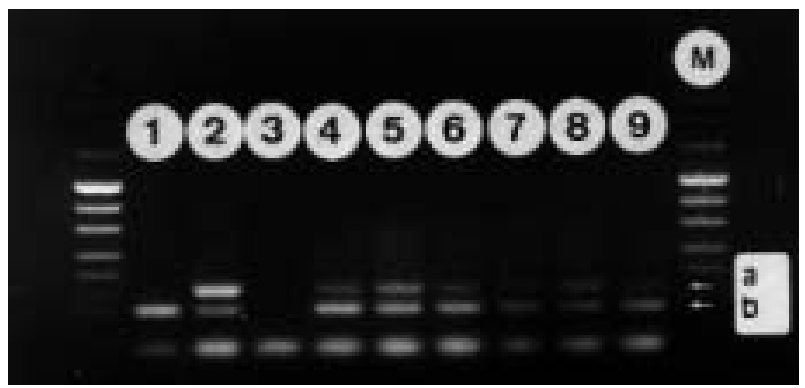

Fig. 3. - Reverse transcriptase polymerase chain reaction (RT-PCR) of MDR1 (a) and $\beta_{2}$ microglobulin transcripts in normal bronchial epithelial cells (lanes 4-9) collected by gentle scraping. Amplified 167 base pair (bp) MDR1 (a) and $114 \mathrm{bp} \beta_{2}$ microglobulin (b) transcripts were separated on a $2 \%$ agarose gel and stained with ethidium bromide. Controls were ribonucleic acid (RNA) template from KB 3.1 (lane 1) and KB 8.5 (lane 2) cells and omitting complementing deoxyribonucleic acid (cDNA) template (lane 3), respectively. M: molecular weight markers.

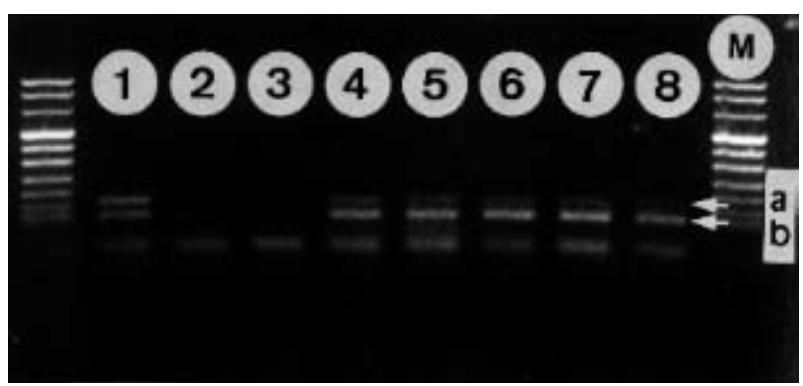

Fig. 4. - Reverse transcriptase polymerase chain reaction (RT-PCR) of MDR1 (a) and $\beta_{2}$ microglobulin (b) transcripts in bronchial epithelial cells from exsmokers (lanes 4-6) and nonsmokers (lanes 7 and 8). Positive control was ribonucleic acid (RNA) template from KB 8.5 cells (lane 1 ). Negative controls were performed by omitting complementing deoxyribonucleic acid (cDNA) (lane 2) or reverse transcriptase (lane 3).

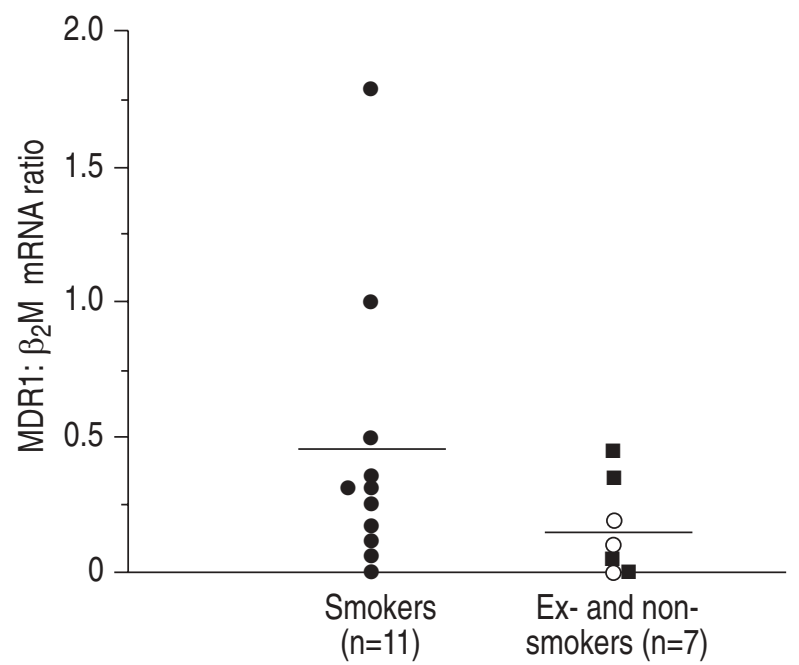

Fig. 5. - Quantitative reverse transcriptase polymerase chain reaction (RT-PCR) by densitometric evaluation of the MDR1 messenger ribonucleic acid (mRNA) cell content compared to $\beta_{2}$ microglobulin $\left(\beta_{2} \mathrm{M}\right)$ mRNA ( smokers, exsmokers and $\bigcirc$ nonsmokers). No statistically significant difference was observed ( $\mathrm{p}=0.18$; nonparametric Mann-Whitney U-test). Horizontal bars represent mean values.
Detection of MDRI mRNA by RT-PCR in bronchial epithelial cells

All samples of bronchial respiratory epithelial cells contained more than $97 \%$ epithelial cells. Epithelial cells were viable as assessed by ciliary movement observed on phase-contrast microscopy. Morphological evaluation by light microscopy of May Grünwald Giemsa stained cytospin preparations showed that cells were well preserved, predominantly ciliated, epithelial bronchial cells.

As illustrated on figures 3 and 4 , after reverse transcription and amplification with MDR1-specific primers, a 167 bp band was detected in 10 of the 11 samples from smokers and in five of the seven samples from exsmokers ( $n=3$ out of 4$)$ and nonsmokers $(n=2$ out of 3$)$. A $114 \mathrm{bp}$ band was observed in all the samples after amplification using specific human $\beta_{2}$ microglobulin primers. The densitometric evaluation of MDR 1 mRNA cell content is shown in figure 5. MDR1 is expressed in smokers as well as in exsmokers and nonsmokers. However, no statistically significant difference was observed ( $\mathrm{p}=0.18$, nonparametric Mann-Whitney U-test).

\section{Discussion}

The MDRl gene codes for a $170-180 \mathrm{kD}$ plasma membrane glycoprotein, the P-glycoprotein, a member of a superfamily of highly conserved $\mathrm{ABC}$ transport proteins. MDR1 cDNA encodes 1,280 amino acids with the presence of 12 transmembrane domains in two homologous halves each containing six transmembrane regions and a large intracytoplasmic loop encoding an ATP binding site $[1,2,11,12]$. In humans, there are at least two $M D R$ genes, $M D R 1$ and $M D R 2 / M D R 3$, sharing extensive amino acid homology, but having different functions $[3,15]$. The two human P-glycoproteins MDR1 and MDR2/MDR3, products of the human MDR1 and $M D R 2 / M D R 3$ genes, have more than $75 \%$ homology of their amino acid residues [15]. Some monoclonal antibodies recognizing intracellular epitopes, such as C494 or JSB1, used for the immunodetection of MDR1 Pgp 170, therefore cross-react with the MDR2/MDR3 P-glycoprotein $[3,22]$. In contrast, MRK16, an antibody directed against MDR1, that does not cross-react with MDR2/MDR3, recognizes an extracellular domain of the protein [23]. Furthermore, MRK16 does not crossreact with other cellular components, in contrast to C219 and JSB1 which have been shown to cross-react with pyruvate carboxylase, a mitochondrial enzyme [26]. C219 also cross reacts with heavy chains of muscle myosin [25]. Therefore, only the staining observed on the cell membrane can be taken into account with the majority of antibodies used for Pgp detection.

The immunohistochemical detection of P-glycoprotein and the detection of MDR1 mRNA clearly show that the MDRl gene is expressed in human bronchial structures analysed in the present study. After total RNA extraction from surface epithelial cells obtained by gentle scraping of the bronchial mucosa, MDR1 mRNA was clearly detected in samples from smokers as well as ex- or nonsmokers. In order to exclude false-positive results by detection of MDR2/MDR3 mRNA, the primers were chosen to prevent amplification of genomic DNA sequences, and were selected so they would not amplify the $M D R 2 / M D R 3$ sequence [29]. 
After immunohistochemical detection using either C494 antibody on paraffin sections or MRK16 antibody on cryostat sections, MDR1 Pgp 170 was detected on the luminal surface of the bronchial epithelium, at the apical membrane of ciliated, but not mucous, cells. Immunodetection of Pgp 170 after incubation with MRK16 antibody was mentioned in bronchial structures by VAN DER VALK et al. [21], but negative results were reported by two other groups $[24,25]$. Such a discrepancy could be explained, at least in part, by the great fragility of the MKR16 determinant imposing fixation prior to snapfreezing. In bronchial glands, MDR1 Pgp 170 was also detected at the apical surface of ciliated cells from the glandular ciliated ducts and at the apicolateral faces of serous acini.

The polarized localization of MDR1 is in favour of vectorial transport, as suggested for other tissues. MDR1 has been detected at the brush border of renal proximal tubular epithelium and the luminal surface of enterocytes [18-21, 24]. The functions of MDR1 in normal tissues are unclear, although its localization suggests a secretory function in excretion of toxic and potentially toxic substances, particularly lipophilic compounds. It has recently been shown that apical membrane vesicles from normal human intestinal epithelium, particularly from colon, transport the carcinogen benzo(a)pryrene $[6,7]$. One hypothesis could be that MDR 1 at the bronchial luminal surface contributes to cell defence mechanisms, particularly against xenobiotics such as those contained in tobacco smoke.

MDR1 Pgp 170 is also expressed in bronchial capillary cells. In brain and testis, MDR has been shown to be part of the "blood-brain" and "blood-testis" permeability barriers [25, 31, 32]. In previous reports [18], after incubation with C219 antibody, little or no Pgp 170 was detected in human capillary endothelial cells of lung and bronchi. In contrast, in the present study, intense staining of the luminal face of endothelial cells was observed, regardless of the antibody used. It can, therefore, be hypothesized that MDR1 Pgp 170 could be part of a "blood-bronchial" permeability barrier to circulating substances.

It has not yet been determined whether the MDRI gene is inducible or constitutional in normal bronchial epithelium. It has been shown in the liver, that $M D R$ genes may be regulated in response to xenobiotics, including chemical carcinogens known to modulate the activity of the cytochrome P450 system [33, 34]. It would be useful to define the regulation of MDR1 Pgp 170 expression in human bronchial epithelial cells, particularly by tobacco smoke components, in order to evaluate the capacity of these defence mechanisms to respond to potentially carcinogenic inhaled xenobiotics. Different levels of expression were observed between individuals in the two groups evaluated, with a higher mean in the smokers group, although with no statistically significant difference.

MDR1 Pgp 170 has been shown to regulate a volume-regulated chloride channel, which could be important in cystic fibrosis [4, 5]. MDR1 Pgp 170 shares homology with the cystic fibrosis transmembrane conductance regulator (CFTR) protein) [1, 35]. Moreover, in a study in the rat, it has been shown that the MDRI and CFTR genes have complementary patterns of epithelial expression in various tissues [36]. In humans, it has been shown that submucosal glands are the predominant site of CFTR expression in the bronchus, particularly in the serous component of the secretory tubules and in a subpopulation of cells in excretory ducts [37]. In contrast, various studies have shown low levels of CFTR mRNA and protein in cells of the surface epithelium [38, 39]. However, in normal epithelium, when using CFTR detection by immunochemistry, the labelling was restricted to the surface apical compartment of the ciliated cells, like that observed for MDR1 Pgp 170 [39]. In glands, for MDR1 as for CFTR [40], the proteins were immunodetected in serous but not in mucous cells, although the labelling for MDR1 was less intense than that observed in the surface epithelial cells. These findings are in agreement with the suggestion that serous cells are more important than mucous cells in providing the fluid component of gland secretion [41]. The present study, therefore, strongly suggests that, in human adult bronchus, MDR1 and CFTR are coexpressed in ciliated epithelial cells and in glandular cells. However, the intense labelling observed on bronchial epithelial cells after incubation with the MRK16 antiMDR 1 antibody is in favour of intense MDR1 expression compared to the results reported for the detection of CFTR in ciliated cells.

In conclusion, MDR1 expression was detected in bronchial epithelial cells from smokers as well as from ex- and nonsmokers. The P-glycoprotein expression at the apical surface of bronchial ciliated cells suggests specific functions for this transmembrane protein localized at the interface between epithelial cells and the bronchial fluid. As these functions could be as varied as epithelial cell defence towards benzo(a)pyrene or modulation of a chloride channel, the regulation of the MDRl gene expression in bronchial epithelial cells is likely to be important in various conditions such as chronic exposure to tobacco smoke, or cystic fibrosis.

Acknowledgements: The authors thank B. Bazelly and P. Callard for their constant support, S. Ricci for her skilful technical assistance and V. Gerber for editorial assistance.

\section{References}

1. Higgins CF. ABC transporters: from microorganisms to man. Ann Rev Cell Biol 1992; 8: 67-113.

2. Gottesman MM, Pastan I. Biochemistry of multidrug resistance mediated by the multidrug transporter. Annu Rev Biochem 1993; 62: 385-427.

3. Bellamy W, Weinstein RS. Functional diversity in the multidrug resistance gene family. Lab Invest 1994; 71: 617-620.

4. Gill DR, Hyde SC, Higgins LF, Valverde MA, Mintenig G, Sepulveda FV. Separation of drug transport and chloride channel functions of the human multidrug resistance P glycoprotein. Cell 1992; 71: 23-32.

5. Hardy SP, Goodfellow HR, Valverde MA, Gill DR, Sepulveda FV, Higgins CF. Protein kinase C mediated phosphorylation of the human multidrug resistance $\mathrm{P}$ glycoprotein regulates cell volume activated chloride channels. EMBO J 1995; 14: 68-75.

6. Yeh GC, Lopaczynska J, Poore LM, Phang JM. A new functional role for $\mathrm{P}$ glycoprotein: efflux pump for 
benzo(a)pyrene in human breast cancer CMF-7 cells. Cancer Res 1992; 52: 6692-6695.

7. Penny JI, Campbell CF. Active transport of benzo(a)pyrene in apical membrane vesicles from normal human intestinal epithelium. Biochim Biophys Acta 1994; 1226: 232-236.

8. Moscow JA, Fairchild CR, Madden MJ, et al. Expression of anionic glutathione $\mathrm{S}$ transferase and $\mathrm{P}$ glycoprotein genes in human tissues and tumors. Cancer Res 1989; 49: 1422-1428.

9. Zaman GJR, Lankelma J, Van Tellingen O, et al. Role of glutathione in the export of compounds from cells by the multidrug-resistance associated protein. Proc Natl Acad Sci USA 1995; 92: 7690-7694.

10. Kartner N, Riodan JR, Ling V. Cell surface P-glycoprotein associated with multidrug resistance in mammalian cell lines. Science 1983; 222: 1285-1288.

11. Roninson IB, Chin JE, Choi K, et al. Isolation of human mdr DNA sequences amplified in multidrug-resistant KB carcinoma cells. Proc Natl Acad Sci USA 1986; 83: 83: 4538-4542.

12. Ueda K, Cardarelli C, Gottesman MM, Pastan I. Expression of full-length cDNA for the human MDR1 gene confers resistance to colchicine, doxorubicin, and vinblastine. Proc Natl Acad Sci USA 1987; 84: 3004-3008.

13. Ueda K, Clark DR, Chen CJ, Roninson IB, Gottesman MM, Pastan I. The human multidrug resistance (mdrl) gene cDNA cloning and transcription initiation. $J$ Biol Chem 1987; 262: 505-508.

14. Chin JE, Soffir R, Noonan KE, Choi K, Roninson IR. Structure and expression of the human MDR (P-glycoprotein) gene family. Mol Cell Biol 1989; 9: 3808-3820.

15. Van Der Bliek A, Kooimon PM, Schneider C, Borst B. Sequence of MDR3 cDNA encoding a human P-glycoprotein. Gene 1988; 71: 401-411.

16. Ruetz S, Gros P. Phosphatidylcholine translocase: a physiological role for the MDR2 gene. Cell 1994; 77: 1071-1081.

17. Smit JJM, Schinkel AH, Mol CCA, et al. Tissue distribution of the human MDR3-P glycoprotein. Lab Invest 1994; 71: 638-649.

18. Cordon-Cardo C, O'Brien JP, Boccia J, Casals D, Bertlno JR, Melamed MR. Expression of the multidrug resistance gene product (P-glycoprotein) in human normal and tumour tissues. J Histochem Cytochem 1990; 30: $1277-1287$

19. Thiebaut F, Tsuruo T, Hamada H, Gottesman MM, Pastan I, Willingham MC. Cellular localization of the multidrug resistance gene product P-glycoprotein in normal human tissues. Proc Natl Acad Sci USA 1987; 84: 7735-7738.

20. Fojo AT, Ueda K, Slamon DJ, Poplack DG, Gottesman MM, Pastan I. Expression of a multidrug-resistance gene in human tumors and tissues. Proc Natl Acad Sci USA 1987; 84: 265-269.

21. Van Der Valk P, Van Kalken CK, et al. Distribution of multidrug-resistance associated P-glycoprotein in normal and neoplastic human tissues. Ann Oncol 1990; 1: 56-64.

22. Georges E, Bradley G, Gariepy J, Ling V. Detection of P-glycoprotein isoforms by gene-specific monoclonal antibodies. Proc Natl Acad Sci USA 1990; 87: 152-156.

23. Georges E, Tsuruo T, Ling V. Topology of P-glycoprotein as determined by epitope mapping of MRK16 antibody. J Biol Chem 1993; 268: 1792-1798.

24. Sugawara I, Kataoka I, Morishita Y, et al. Tissue distribution of P-glycoprotein encoded by a multidrugresistant gene as revealed by a monoclonal antibody MRK16. Cancer Res 1988; 48: 1926-1929.

25. Thiebaut F, Tsuruo T, Hamada H, Gottesman M, Pastan I, Willingham M. Immunohistochemical localization in normal tissues of different epitopes in the multidrug transport protein P170: evidence for localization in brain capillaries and crossreactivity of one antibody with muscle protein. J Histochem Cytochem 1989; 37: 159-164.

26. Vallabhaneni VR, Anthony DC, Piwnica-Worms D. MDR1 gene-specific monoclonal antibody C494 crossreacts with pyruvate carboxylase. Cancer Res 1994; 54: 1536-1541.

27. Weinstein R, Kuszak J, Jakate S, Lebovitz M, Kluskens L, Coon J. ABO blood type predicts the cytolocalization of anti-P-glycoprotein monoclonal antibody reactivity in human colon and ureter. Hum Pathol 1990; 21: 949-958.

28. Chomszynski P, Sacchi N. Single step method of RNA isolation by acid guanidium thiocyanate-phenol-chloroform extraction. Anal Biochem 1987; 162: 156-159.

29. Noonan KE, Beck C, Holzmeyer TA, et al. Quantitative analysis of MDR1 (multidrug resistance) gene expression in human tumors by polymerase chain reaction. Proc Natl Acad Sci USA 1990; 87: 7160-7164.

30. Meyrick B, Sturgess JM, Reid L. A reconstruction of the duct system and secretory tubules of the human bronchial submucosal gland. Thorax 1969; 24: 729-736.

31. Cordon-Cardo C, O'Brien JP, Casals D, et al. Multidrugresistance gene (P-glycoprotein) is expressed by endothelial cells at blood-brain barrier sites. Proc Natl Acad Sci USA 1989; 86: 695-698.

32. Tatsuta T, Naito M, Oh-Hara T, Sugawara I, Tsuruo T. Functional involvement of P-glycoprotein in bloodbrain barrier. J Biol Chem 1992; 267: 20383-20391.

33. Thorgeirsson SS, Huber BE, Sorrerl S, Fojo A, Pastan I, Gottesman MM. Expression of the multidrug-resistant gene in hepatocarcinogenesis and regenerating rat liver. Science 1987; 236: 1120-1122.

34. Burt RK, Thorgeirsson SS. Coinduction of MDR-1 multidrug-resistance and cytochrome P-450 genes in rat liver by xenobiotics. J Natl Cancer Inst 1988; 80: 1383-1386.

35. Hyde SC, Emsley P, Hartshorn MJ, et al. Structural model of ATP-binding proteins associated with cystic fibrosis, multidrug resistance and bacterial transport. Nature 1990; 346: 362-365.

36. Trezise AEO, Romano P, Gill D, et al. The multidrug resistance and cystic fibrosis genes have complementary patterns of epithelial expression. EMBO J 1992; 11: 4291-4303.

37. Engelhardt JF, Yankaskas JR, Ernst SA, et al. Submucosal glands are the predominant site of CFTR expression in the human bronchus. Nature Genetics 1992; 2: 240248.

38. Trapnell BC, Chu CS, Paakko PK, et al. Expression of the cystic fibrosis transmembrane conductance regulator gene in the respiratory tract of normal individuals and individuals with cystic fibrosis. Proc Natl Acad Sci USA 1991; 88: 6565-6569.

39. Puchelle E, Gaillard D, Ploton D, et al. Differential localization of the cystic fibrosis transmembrane conductance regulator in normal and cystic fibrosis airway epithelium. Am J Respir Cell Mol Biol 1992; 7: 485-491.

40. Jacquot J, Puchelle E, Hinnrasky J, et al. Localization of the cystic fibrosis transmembrane conductance regulator in airway secretory glands. Eur Respir J 1993; 6: 169-176.

41. Finkbeiner WE, Shen BQ, Widdicombe JH. Chloride secretion and function of serous and mucous cells of human airway glands. Am J Physiol (Lung Cell Mol Physiol 11) 1994; 267: L206-L210. 